\title{
Penile Epithelioid Hemangioendothelioma
}

National Cancer Institute

\section{Source}

National Cancer Institute. Penile Epithelioid Hemangioendothelioma. NCI Thesaurus.

Code C162581.

An epithelioid hemangioendothelioma that occurs in the penis. 